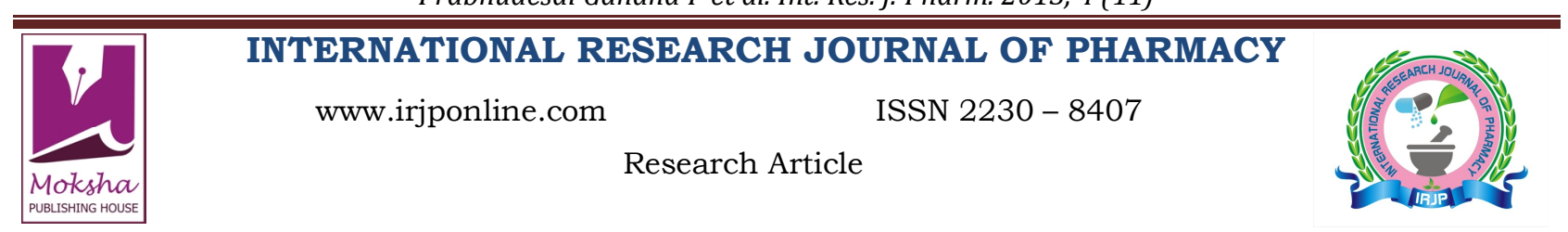

\title{
FABRICATION AND CHARACTERIZATION OF GASTRORETENTIVE MUCOADHESIVE MICRO-PARTICULATE SYSTEM OF PIOGLITAZONE HYDROCHLORIDE FOR SUSTAINED DELIVERY
}

\author{
Prabhudesai Gandha P.*, Gude Rajashree \\ Goa College of Pharmacy, $18^{\text {th }}$ June Road, Panjim, Goa, India \\ *Corresponding Author Email: gandhaprabhudesai@yahoo.com
}

Article Received on: 19/09/13 Revised on: 07/10/13 Approved for publication: 19/11/13

DOI: 10.7897/2230-8407.041114

IRJP is an official publication of Moksha Publishing House. Website: www.mokshaph.com

(c) All rights reserved.

\begin{abstract}
The present study was conducted to formulate and evaluate Gastro retentive Micro-particulate drug delivery system of Pioglitazone Hydrochloride ( $\mathrm{HCl}$ ) for sustained delivery. Pioglitazone Hydrochloride microspheres were prepared by Orifice-Ionotropic Gelation method using a blend of sodium alginate and different mucoadhesive polymers such as Carbopol 934P, Hydroxy Propyl Methyl Cellulose (HPMC, E 50 Low Viscosity) and Sodium Carboxy Methyl Cellulose (SCMC). Totally 16 different formulations of Pioglitazone Hydrochloride were prepared. The microspheres were characterized for Percentage yield, Micromeritic properties, Particle size, entrapment efficiency, shape and surface morphology studies by Scanning Electron Microscope, mucoadhesivity, swelling index, in-vitro drug release and stability studies. The resulting microspheres were small, discrete, spherical and free flowing. Entrapment Efficiency of Pioglitazone Hydrochloride was found to be between $55 \%-106 \%$. Release was sustained for up to 8 hours. The kinetic modelling of the release data indicate that Pioglitazone hydrochloride release from the alginate microspheres followed first order kinetics and the drug release mechanism was found to be Fickian diffusion erosion controlled. Gastro retentive Microspheres of Pioglitazone Hydrochloride is a potential Sustained release drug delivery system for increasing the efficiency of the dose as well as the patient compliance.

Keywords: Mucoadhesive microspheres, Gastro retentive, orifice ionotropic gelation, Pioglitazone Hydrochloride.
\end{abstract}

\section{INTRODUCTION}

Diabetes is a major health problem being faced by modern society of today all over the world. The most common form of diabetes is type 2 diabetes. The relatively brief gastric emptying time (GET) in humans which normally averages 2 $3 \mathrm{~h}$ through the major absorption zone, i.e., stomach and upper part of the intestine can result in incomplete drug release from the drug delivery system leading to reduced efficacy of the administered dose. Gastro retentive dosage forms has received significant interest in the past few decades as they can improve the limitation of most conventional and oral controlled release drug delivery system related to fast gastric-emptying time. Mucoadhesive Microspheres is one such potential strategy. ${ }^{1}$ Microspheres are small spherical particles (typically $1 \mu \mathrm{m}$ to $1000 \mu \mathrm{m}$ ), sometimes referred to as micro particles. The microspheres can be made up of either natural or synthetic polymers. Mucoadhesive microspheres enhance the intimate contact with the mucus layer, and drug targeting to the absorption site by anchoring bacterial adhesions, plant lectins, antibodies etc. The main objective of such a drug delivery system is to control the release profile of the drug and also to sustain the drug release.,

\section{Pioglitazone Hydrochloride}

A thiazolidinedione anti diabetic agent was selected as a drug candidate in the present study. Pioglitazone $\mathrm{HCl}$ has the $\mathrm{pKa}$ value of 4.9 , so it is largely present in unionized form and well absorbed from the acidic $\mathrm{pH}$ of the stomach than the basic $\mathrm{pH}$ condition of intestine. Also the drug is having short biological half life of 3 to $4 \mathrm{~h}$ and hence is suitable for the sustained release dosage. ${ }^{4,5}$ The drug was entrapped in alginate microspheres and then incorporated in a capsule. To overcome problems associated with the conventional system, we aimed to develop Mucoadhesive microspheres which can sustain and localize the drug in the stomach for an effective treatment. Mucoadhesive approach for gastro retention offer the following advantages; improved patient compliance, better control of disease condition, better control of plasma levels and decrease in the total amount of dose administered. ${ }^{6}$

\section{MATERIALS AND METHODS \\ Materials}

Pioglitazone Hydrochloride was gifted by Ranbaxy Laboratories Limited, Goa, India. Sodium Alginate was received as a gift from Snap Natural and Alginate Products Pvt Ltd, Tamil Nadu, India. Carbopol 934 was obtained from Loba chemicals Mumbai, India. HPMC E 50 LV was obtained as gift sample from Colorcon Asia Pvt. Ltd. Goa, India. All other chemicals used were of Analytical grade.

Preparation of Pioglitazone Hydrochloride Mucoadhesive Microspheres

Mucoadhesive microspheres containing Pioglitazone Hydrochloride were prepared by Ionotropic Gelation technique. The required quantities of sodium alginate and the mucoadhesive polymer were dissolved in purified water to form a homogenous polymer solution. The drug, Pioglitazone Hydrochloride $(0.1 \mathrm{~g})$ was added to the polymer solution and mixed homogenously to get a smooth viscous dispersion. The resulting dispersion was then added drop wise into calcium chloride $(5 \% \mathrm{w} / \mathrm{v})$ solution through a syringe using a $22 \mathrm{G}$ needle with continuous stirring at $200 \mathrm{rpm}$. The stirring was continued for 30 minutes to complete the curing reaction and to produce the spherical rigid microspheres. The microspheres were collected by decantation, and the product thus separated was washed repeatedly with water and dried at $45^{\circ} \mathrm{C}$ for 4 hours ${ }^{7,8}$. 
Table 1: It shows the Formulation Composition

\begin{tabular}{|c|c|c|c|c|c|}
\hline Formulation code & $\begin{array}{l}\text { Drug } \\
\text { qty }\end{array}$ & \multicolumn{2}{|c|}{$\begin{array}{l}\text { Ratio of sodium alginate: } \\
\text { Mucoadhesive polymer }\end{array}$} & $\begin{array}{c}\text { Qty of sodium } \\
\text { Alginate }\end{array}$ & $\begin{array}{c}\text { Qty of } \\
\text { Mucoadhesive polymer }\end{array}$ \\
\hline F1 & \multirow{16}{*}{$\begin{array}{l}100 \\
\mathrm{mg}\end{array}$} & \multicolumn{2}{|c|}{$2 \%$ Sod. Alginate } & $1 \mathrm{~g}$ & - \\
\hline F2 & & \multicolumn{2}{|c|}{$3 \%$ Sod. Alginate } & $1.5 \mathrm{~g}$ & - \\
\hline F3 & & \multicolumn{2}{|c|}{$4 \%$ Sod. Alginate } & $2 \mathrm{~g}$ & - \\
\hline F4 & & \multicolumn{2}{|c|}{$5 \%$ Sod. Alginate } & $2.5 \mathrm{~g}$ & - \\
\hline F5 & & $1: 1$ & \multirow{4}{*}{$\begin{array}{c}\text { Carbopol } \\
934 \mathrm{P}\end{array}$} & $500 \mathrm{mg}$ & $500 \mathrm{mg}$ \\
\hline F6 & & $3: 1$ & & $750 \mathrm{mg}$ & $250 \mathrm{mg}$ \\
\hline F7 & & $5: 1$ & & $835 \mathrm{mg}$ & $165 \mathrm{mg}$ \\
\hline F8 & & $7: 1$ & & $875 \mathrm{mg}$ & $125 \mathrm{mg}$ \\
\hline F9 & & $1: 1$ & \multirow{4}{*}{$\begin{array}{l}\text { HPMC } \\
\text { E50 LV }\end{array}$} & $500 \mathrm{mg}$ & $500 \mathrm{mg}$ \\
\hline F10 & & $3: 1$ & & $750 \mathrm{mg}$ & $250 \mathrm{mg}$ \\
\hline F11 & & $5: 1$ & & $835 \mathrm{mg}$ & $165 \mathrm{mg}$ \\
\hline F12 & & $7: 1$ & & $875 \mathrm{mg}$ & $125 \mathrm{mg}$ \\
\hline F13 & & $1: 1$ & \multirow{4}{*}{ SCMC } & $500 \mathrm{mg}$ & $500 \mathrm{mg}$ \\
\hline F14 & & $3: 1$ & & $750 \mathrm{mg}$ & $250 \mathrm{mg}$ \\
\hline F15 & & $5: 1$ & & $835 \mathrm{mg}$ & $165 \mathrm{mg}$ \\
\hline F16 & & $7: 1$ & & $875 \mathrm{mg}$ & $125 \mathrm{mg}$ \\
\hline
\end{tabular}

\section{Evaluation of Microspheres}

Particle Size analysis

Microscopic analysis was performed to determine average size of microspheres. The microspheres prepared were dispersed in liquid paraffin. A drop of the above dispersion was put on a glass slide and observed under the microscope. The diameter of 100 microspheres was determined using a calibrated eye piece micrometer and stage micrometer. The average diameter was calculated using the formula $a^{10-15}$.

Average Size $=\Sigma \mathrm{nd} / \Sigma \mathrm{n}$

Where, $\mathrm{n}$ is the number of microspheres and $\mathrm{d}$ is the size of microsphere

\section{Percentage yield (\% w/w)}

The percentage yield of each batch was calculated on weight basis with respect to the weight of the starting material.

$$
\text { Percentage yield }=\frac{\text { weight of miorospheres }}{\text { amount of dugtexcipients }} \times 100
$$

\section{Drug Loading and Entrapment efficiency}

Entrapment efficiency is the percentage of drug entrapped in the microspheres related to the initial quantity of the drug used in the formulation. $50 \mathrm{mg}$ of microspheres were taken and crushed in a glass mortar pestle. The drug was extracted from the ground microspheres using $0.1 \mathrm{~N} \mathrm{HCl}$ in a $100 \mathrm{~mL}$ volumetric flask. The Solution was filtered through Whatmann filter paper no. 41. The Absorbance of the resulting solution was measured at wavelength maximum of $269 \mathrm{~nm}$ using double beam UV-Visible Spectrophotometer with $1 \mathrm{~cm}$ path length sample cells.

$$
\begin{aligned}
& \text { Drug Loading }(\%)= \\
& \frac{\text { weight of drug in mucsadhesive microspheres }}{\text { weisht of mucoadhesive microspheres }} \times 100
\end{aligned}
$$

Entrapment efficiency was calculated using the following formula:

$$
\text { Entrapment efficiency }(\%)=\frac{\text { calculated drug content }}{\text { theoretioal drug content }} \times 100
$$

\section{Micromeritic properties of microspheres}

Determination of bulk density

Bulk density of the formulations was determined by using the following formula:

$$
\text { Bulk density }=\frac{\text { gample weight }}{\text { sample volume }}
$$

\section{Determination of tapped density}

Tapped density is used to investigate packing properties of microspheres into capsules. The tapped density was measured by employing the conventional tapping method using a 10 $\mathrm{mL}$ measuring cylinder and the number of tapping's was 100 as sufficient to bring a plateau condition. Tapped density was calculated using the following formula:

$$
\text { Tapped density }=\frac{\text { weight of microshzres }}{\text { volume of microspheres after } 100 \text { tappings }} \times
$$

\section{Hausner's ratio}

It is another parameter for measuring flow ability of the microspheres. It is calculated using the following formula,

$$
\text { Hausner's ratio }=\frac{\text { volume before tapping }}{\text { valume after tapping }} \times 100
$$

\section{Carr's index}

The Carr index is an indication of the compressibility of a powder. A Carr index greater than 25 is considered to be an indication of poor flow ability, and below 15, of good flow ability. It is indirect measurement of bulk density, size and shape, surface area, moisture content, and cohesiveness of materials since all of them can influence the consolidation index. It is denoted by $\mathrm{Ci}$ and is calculated using the formula below.

$$
\mathrm{Ci}=\frac{\text { Tapped density }- \text { Bulkdensity }}{\text { Bulk dunsl Ly }} \times 100
$$

\section{Shape and surface characterization}

The shape and surface characterization of microspheres were observed under a Scanning Electron Microscope (SEM). The microspheres were mounted directly on the SEM sample stub, using double-sided sticking tape, and photographed.

\section{Swelling Index}

The swelling studies were carried out for prepared microspheres. A known weight $(100 \mathrm{mg})$ of microspheres was placed in a $100 \mathrm{ml}$ volumetric flask containing $0.1 \mathrm{~N}$ $\mathrm{HCl}$ at $37 \pm 0.50^{\circ} \mathrm{C}$ for $6 \mathrm{~h}$ of the study period. At the end of 
$6 \mathrm{~h}$, the microspheres were removed from the solution, blotted with filter paper and weighed. Finally, the weight of the swollen microspheres was recorded, and the swelling ratio (SR) was then calculated from the formula. The studies were carried out in triplicate.

$$
\text { Swelling Index }=\frac{W e-W o}{W o} \times 100
$$

Where, $\mathrm{Wo}_{\mathrm{N}}=$ Initial weight of the dry microspheres, $\mathrm{We}=$ weight of the swollen microspheres at equilibrium swelling in the media

\section{In vitro wash-off test/ Mucoadhesivity study}

The mucoadhesive properties of the microspheres were evaluated by the In vitro wash-off test. A $4 \mathrm{~cm} \mathrm{x} 4 \mathrm{~cm}$ piece of goat intestine mucosa was tied onto the paddle bottom of USP dissolution test apparatus II using thread. 100 Microspheres were spread onto the wet, rinsed, tissue specimen. Then mucoadhesivity study was carried out in USP II paddle type dissolution test apparatus. It was operated such that the tissue specimen was rotated at a speed of 25 rpm in the using simulated gastric fluid USP ( $\mathrm{pH} 1.2)$ as the medium for 8 hours. At the end of 8 hours, the number of microspheres still adhering on to the tissue was counted.

$\%$ Mucoadhesion $=\frac{\text { number of adhered minuspheres }}{\text { number of applied microspheres }} \times 100$

\section{In vitro release studies}

In vitro drug release study was carried out in USP I basket type dissolution test apparatus using $0.1 \mathrm{~N} \mathrm{HCl}(\mathrm{pH} \mathrm{1.2)} \mathrm{as}$ dissolution medium, volume of dissolution medium was 900 $\mathrm{ml}$ and bath temperature was maintained at $37 \pm 1{ }^{\circ} \mathrm{C}$ throughout the study. Basket speed was adjusted to $50 \mathrm{rpm}$. An interval of 1 hour, $10 \mathrm{ml}$ of sample was withdrawn with replacement of $10 \mathrm{ml}$ fresh medium and analyzed for drug content by UV Visible spectrophotometer at $269 \mathrm{~nm}$. Cumulative percentage drug release was calculated using an equation obtained from a standard curve.

\section{Stability studies}

Stability studies of the microsphere formulations were carried out to study the effect of storage conditions on the formulation properties. The optimum formulation was wrapped in aluminium foil and packed in glass vials. The formulations were then stored at room temperature $\left(25-30^{\circ} \mathrm{C}\right)$ and at $40 \pm 0.5^{\circ} \mathrm{C}$ and $75 \pm 5 \% \mathrm{RH}$ for 1 month. The formulation was periodically evaluated for particle size and drug release.

\section{RESULTS}

\section{Appearance}

The microspheres were spherical, discrete and free flowing.

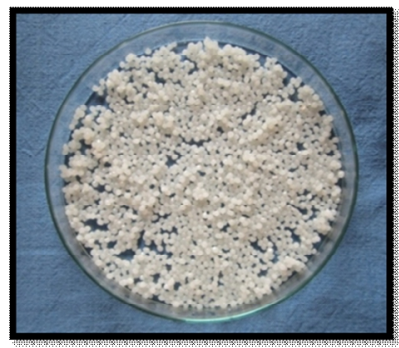

Figure 1: (a) Microspheres before drying

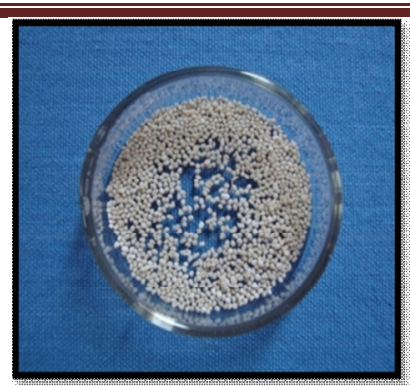

(b) Microspheres after drying

\section{Percentage yield}

Table 2: It shows the Percentage yield results

\begin{tabular}{|c|c|}
\hline Formulation Code & Percentage Yield (\%) \\
\hline F1 & 95.09 \\
\hline F2 & 88.31 \\
\hline F3 & 83.09 \\
\hline F4 & 67.54 \\
\hline F5 & 89.81 \\
\hline F6 & 98 \\
\hline F7 & 87.54 \\
\hline F8 & 81.09 \\
\hline F9 & 120.45 \\
\hline F10 & 94.36 \\
\hline F11 & 86.90 \\
\hline F12 & 106.36 \\
\hline F13 & 115.81 \\
\hline F14 & 104.73 \\
\hline F15 & 96 \\
\hline F16 & 107.54 \\
\hline
\end{tabular}

The Percentage yield was found to be in the range of $67-$ $120 \%$ as shown in table no. 2 .

\section{Particle size}

Table 3: It shows the Particle size

\begin{tabular}{|c|c|}
\hline Formulation code & Particle size \\
\hline F1 & $526.66 \pm 55.0757 \mu \mathrm{m}$ \\
\hline F2 & $673.33 \pm 32.1455 \mu \mathrm{m}$ \\
\hline F3 & $930 \pm 62.4499 \mu \mathrm{m}$ \\
\hline F4 & $1.066 \pm 3.5118 \mathrm{~mm}$ \\
\hline F5 & $960 \pm 60.8276 \mu \mathrm{m}$ \\
\hline F6 & $963.33 \pm 41.6333 \mu \mathrm{m}$ \\
\hline F7 & $966.67 \pm 25.1661 \mu \mathrm{m}$ \\
\hline F8 & $1.006 \pm 0.01527 \mathrm{~mm}$ \\
\hline F9 & $610 \pm 60 \mu \mathrm{m}$ \\
\hline F10 & $730 \pm 45.8257 \mu \mathrm{m}$ \\
\hline F11 & $813.33 \pm 20.8166 \mu \mathrm{m}$ \\
\hline F12 & $870 \pm 26.4575 \mu \mathrm{m}$ \\
\hline F13 & $740 \pm 45.8257 \mu \mathrm{m}$ \\
\hline F14 & $870 \pm 43.5889 \mu \mathrm{m}$ \\
\hline F15 & $866.67 \pm 15.2752 \mu \mathrm{m}$ \\
\hline F16 & $896.67 \pm 25.1661 \mu \mathrm{m}$ \\
\hline
\end{tabular}

The particle size of microspheres ranges from 1-1000 $\mu \mathrm{m}$. In the present study, the average particle size of mucoadhesive microspheres prepared from the combination of Sodium alginate and mucoadhesive polymers was found to be in the range of $526 \mu \mathrm{m}-1 \mathrm{~mm}$ as shown in Table 3 . The F4 formulation microspheres had larger particle size as compared to the other formulations, probably due to the higher viscosity of Sodium alginate. The average particle size of the optimum formulation F5 was found to be $960 \pm$ $60.8276 \mu \mathrm{m}$. 


\section{Percent Drug Loading and Entrapment Efficiency}

Table 4: It shows Percent Drug loading and Entrapment Efficiency of the prepared microspheres

\begin{tabular}{|c|c|c|}
\hline $\begin{array}{c}\text { Formulation } \\
\text { code }\end{array}$ & $\begin{array}{c}\text { Percent drug } \\
\text { loading }\end{array}$ & $\begin{array}{c}\text { Entrapment efficiency } \\
\text { (\%) }\end{array}$ \\
\hline F1 & 5.8 & $60.67 \%$ \\
\hline F2 & 5.17 & $73.02 \%$ \\
\hline F3 & 5.73 & $103.14 \%$ \\
\hline F4 & 5.79 & $98.34 \%$ \\
\hline F5 & 7.07 & $97.03 \%$ \\
\hline F6 & 6.8 & $106.68 \%$ \\
\hline F7 & 10.92 & $95.09 \%$ \\
\hline F8 & 13.31 & $84.29 \%$ \\
\hline F9 & 5.86 & $97.95 \%$ \\
\hline F10 & 11 & $57.65 \%$ \\
\hline F11 & 9.43 & $69.63 \%$ \\
\hline F12 & 7.21 & $78.97 \%$ \\
\hline F13 & 5.98 & $76.28 \%$ \\
\hline F14 & 5.44 & $62.67 \%$ \\
\hline F15 & 5.33 & $56.34 \%$ \\
\hline F16 & 5.32 & $62.88 \%$ \\
\hline
\end{tabular}

The entrapment efficiency was in the range of $55 \%$ to $106 \%$ being highest for F6 and lowest for F15 as shown in Table 4.

\section{Micromeritic properties}

Table 5: It shows micromeritic properties of the prepared microspheres

\begin{tabular}{|c|c|c|c|c|}
\hline $\begin{array}{c}\text { Formulation } \\
\text { code }\end{array}$ & $\begin{array}{c}\text { Bulk } \\
\text { density }\end{array}$ & $\begin{array}{c}\text { Tapped } \\
\text { density }\end{array}$ & $\begin{array}{c}\text { Carr's } \\
\text { index }\end{array}$ & $\begin{array}{c}\text { Hausner } \\
\text { Ratio }\end{array}$ \\
\hline F1 & 0.6944 & 0.7562 & 8.8997 & 1.0889 \\
\hline F2 & 0.9375 & 0.9764 & 4.1493 & 1.0414 \\
\hline F3 & 0.9090 & 0.9376 & 3.1463 & 1.0314 \\
\hline F4 & 0.8823 & 0.9627 & 9.1125 & 1.0911 \\
\hline F5 & 0.5769 & 0.6857 & 18.8594 & 1.1885 \\
\hline F6 & 0.5357 & 0.5729 & 6.9441 & 1.0694 \\
\hline F7 & 0.5172 & 0.6234 & 20.5336 & 1.2053 \\
\hline F8 & 0.8333 & 0.9864 & 18.3727 & 1.1117 \\
\hline F9 & 0.625 & 0.764 & 22.24 & 1.2224 \\
\hline F10 & 0.5769 & 0.5983 & 3.7094 & 1.0370 \\
\hline F11 & 0.7142 & 0.8132 & 13.8616 & 1.1386 \\
\hline F12 & 0.7692 & 0.8821 & 14.6775 & 1.1467 \\
\hline F13 & 0.4285 & 0.4763 & 11.1551 & 1.1115 \\
\hline F14 & 0.5 & 0.5676 & 13.52 & 1.1352 \\
\hline F15 & 0.6666 & 0.7743 & 16.1566 & 1.1615 \\
\hline F16 & 0.5555 & 0.6354 & 14.3834 & 1.1438 \\
\hline
\end{tabular}

Inter particulate interaction is one of the most important parameter that affects the bulk and flow characteristics of powder. The studies of flow characteristics suggested that an improvement was found in values of bulk density, tap density as described in Table 14 on developing microsphere formulation of Pioglitazone $\mathrm{HCl}$, and indicated that the microspheres had good pack ability and enhanced flow ability. In this study, Carr's index of most of the formulations was found to be below 15 which indicated good flow ability.

\section{Shape and surface characterization}

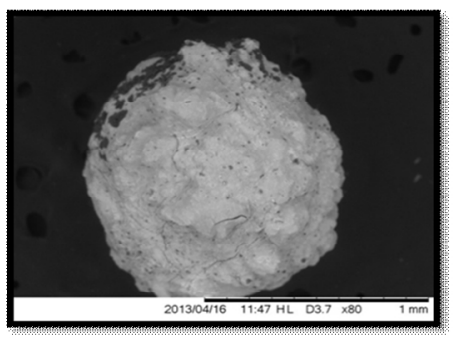

a) under $x \mathbf{8 0}$

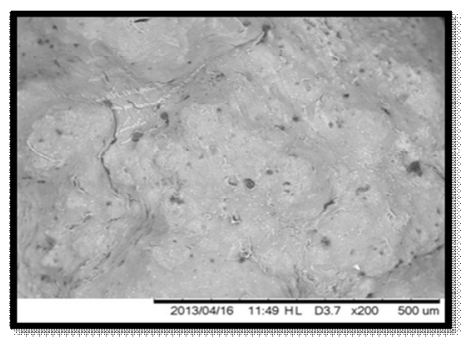

b) under $x 200$

Figure 2: It shows the SEM photograph of F5 (Sodium Alginate + Carbopol)

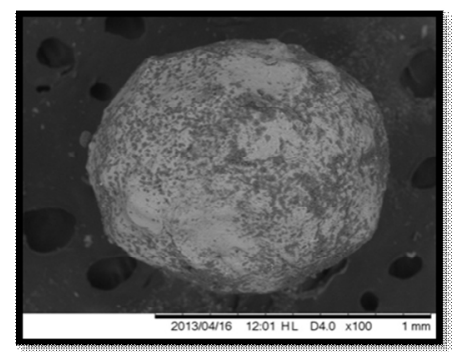

a) under $x 100$

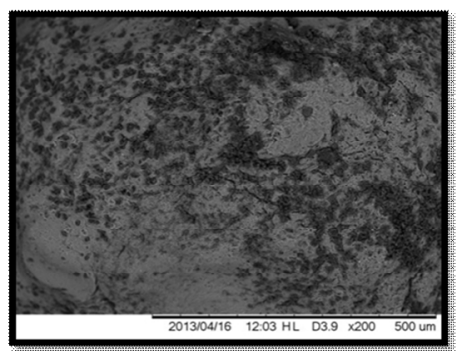

b) under x 200

Figure 3: It shows the SEM photograph of Sodium Alginate + HPMC E50 LV

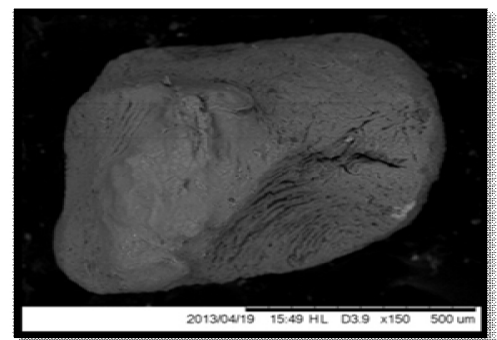

a) under $x 150$

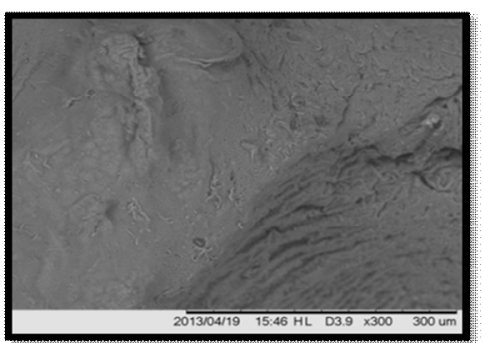

b) under $\mathrm{x} 300$

Figure 4: It shows the SEM photograph of Sodium Alginate + SCMC

The morphological evaluation of the microsphere formulations was done by scanning electron microscopy. SEM study revealed that the HPMC and Carbopol 934P 
microspheres were almost spherical in shape whereas SCMC microspheres were eccentric in shape due to the low viscosity of SCMC. HPMC and SCMC microspheres had smooth surface whereas Carbopol 934P microspheres had rough outer surface.

\section{Swelling Index}

Table 6: It shows the Swelling Index of the prepared microspheres

\begin{tabular}{|c|c|}
\hline Formulation code & Swelling index (\%) \\
\hline F1 & $7 \%$ \\
\hline F2 & $8 \%$ \\
\hline F3 & $12 \%$ \\
\hline F4 & $5 \%$ \\
\hline F5 & $97 \%$ \\
\hline F6 & $23 \%$ \\
\hline F7 & $12 \%$ \\
\hline F8 & $5 \%$ \\
\hline F9 & $4 \%$ \\
\hline F10 & $30 \%$ \\
\hline F11 & $47 \%$ \\
\hline F12 & $21 \%$ \\
\hline F13 & $18 \%$ \\
\hline F14 & $12 \%$ \\
\hline F15 & $8 \%$ \\
\hline F16 & $3 \%$ \\
\hline
\end{tabular}

Swell ability is an indicative parameter for rapid availability of the drug solution for diffusion with greater flux. The highest swelling index was shown by formulation F5. It was found that by increasing the concentration of the mucoadhesive polymer, swelling of microspheres was increased. This could be due to the high absorbing capacity of the polymers. (Table 6)

\section{In vitro wash off test}

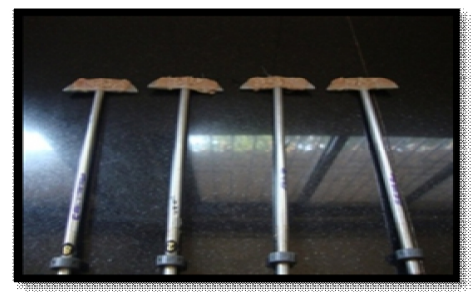

Figure 5: It shows the Mucoadhesive microspheres

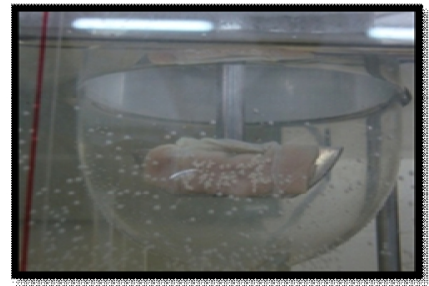

Figure 6: It shows the Mucoadhesive before the test microspheres during the test

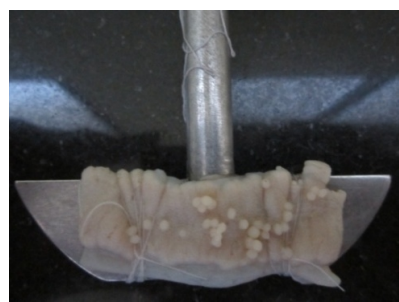

(a) It shows the Mucoadhesive microspheres

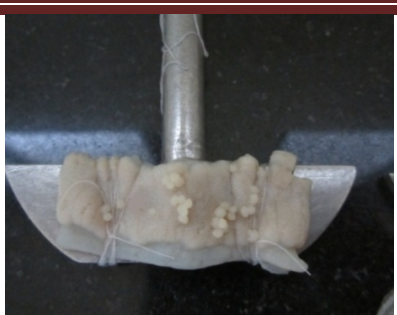

(b) It shows the Mucoadhesive at initial (F5) microspheres after 8 h (F5) Figure 7

From the in vitro evaluation of mucoadhesion, it was observed that as the concentration of mucoadhesive polymer increases the adhesion property also increased. It was found that plain alginate microspheres showed less mucoadhesivity as compared to microspheres with a mucoadhesive polymer. The highest percent mucoadhesion was shown by F5 and F13 which is probably due to greater content of the highly mucoadhesive polymers, SCMC and carbopol $934 \mathrm{P}$.

\section{In vitro Cumulative Drug Release}

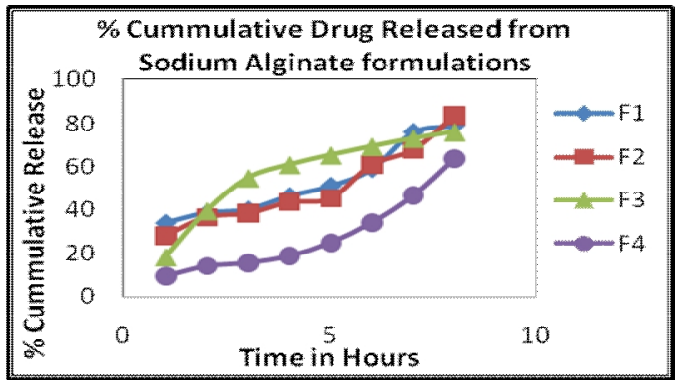

Figure 8: Comparison of \% Cumulative Drug Release

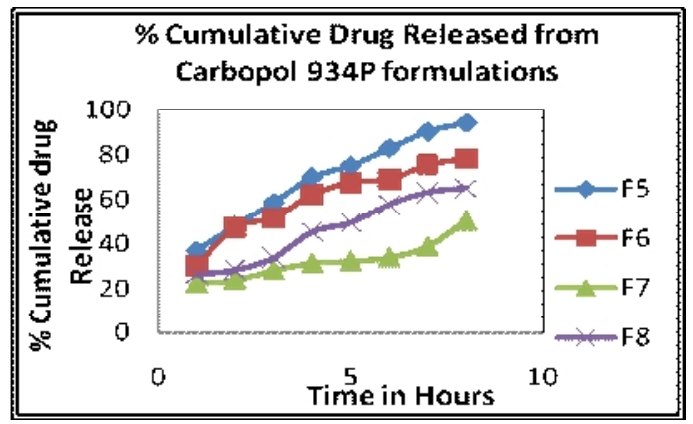

Figure 9: Comparison of \% Cumulative Drug from all Sodium Alginate formulations

Release from all Carbopol 934P formulations

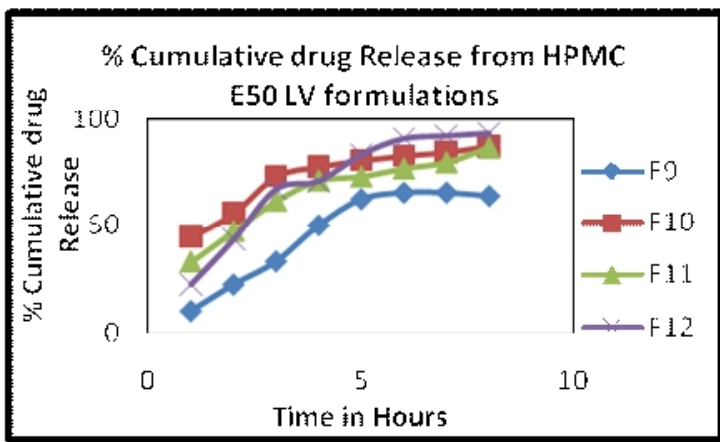

Figure 10: Comparison of \% Cumulative Drug from 


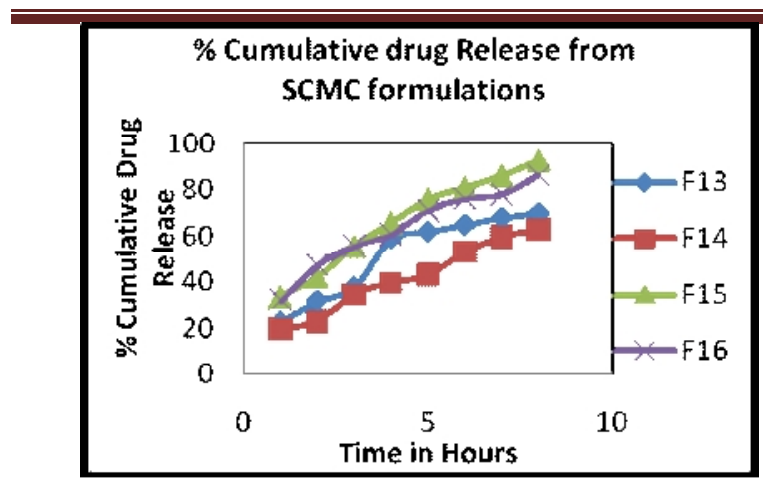

Figure 11: Comparison of \% Cumulative Drug Release from all HPMC E50 LV formulations

Release all SCMC formulations

\section{Stability studies}

The results of stability testing are shown in the Table 10 . The drug release after 15 and 30 days was calculated and is shown below. The results indicate that the maximum percent cumulative drug released was observed at room temperature than at accelerated conditions after 1 months study.

Table 7: It shows Results of stability testing

\begin{tabular}{|c|c|c|}
\hline & \multicolumn{2}{|c|}{ \% Drug released after following days } \\
\hline Temperature & 15 & 30 \\
\hline Room Temperature & $91.65 \%$ & $92.92 \%$ \\
\hline Accelerated Temperature & $89.10 \%$ & $87.83 \%$ \\
\hline
\end{tabular}

\begin{tabular}{|c|c|c|}
\hline \multirow{2}{*}{} & \multicolumn{2}{|c|}{ Particle Size after following days } \\
\cline { 2 - 3 } & 15 & 30 \\
\hline Particle Size & $951.66 \mu \mathrm{m}$ & $953.33 \mu \mathrm{m}$ \\
\hline
\end{tabular}

\section{DISCUSSION}

On the basis of pre formulation studies done on various polymers, selection of polymers to design Gastro retentive Micro-particulate drug delivery system of Pioglitazone hydrochloride was narrowed down to Carbopol 934P, SCMC and HPMC E50 LV. A set of 16 microsphere formulation batches were devised using the above polymers in different concentrations. The microspheres were prepared by orifice ionotropic gelation technique. The microspheres were evaluated for percentage yield, Micromeritic properties, Particle size, entrapment efficiency, shape and surface morphology studies by SEM, mucoadhesivity studies and in vitro drug release. Cumulative percent release data revealed that formulation F5 showed better dissolution profile with $94.20 \%$ drug released in 8 hours. As the result the prepared microspheres remained adhered to the gastric mucosa for prolonged period where they released drug in a sustained manner before being eroded off. Formulated gastro retentive microspheres best fitted first order kinetics and followed Fickian diffusion mechanism along with the erosion of the microsphere matrix. It was observed that with increase in the mucoadhesive polymer, mucoadhesion increases and the drug release decreases. This is attributed to the greater degree of swelling upon hydration with greater mucoadhesive polymer content in the microspheres which leads to increase in the diffusional path length that slows the drug release. Stability studies on microspheres performed for a period of 1 month exhibited no significant variations.

\section{CONCLUSION}

Sustained release mucoadhesive microspheres were successfully prepared by employing orifice ionotropic gelation technique. Microspheres prepared are spherical in shape with rough outer surface. It was observed that with increase in the mucoadhesive polymer, mucoadhesion increases and the drug release decreases. This is attributed to the greater degree of swelling upon hydration with greater mucoadhesive polymer content in the microspheres which leads to increase in the diffusional path length that slows the drug release. F5 formulation showed maximum mucoadhesivity. The drug entrapment efficiency was found to be within the range of 55 to $105 \%$. The microspheres were found to be effective in sustaining the drug release. Among all the 16 formulations, F5 showed better dissolution profile with $94.20 \%$ drug released in 8 hours. Stability studies indicated that there was no significant change in particle size, drug content and dissolution profile of microspheres. The drug release kinetics indicated that the drug release from the microspheres followed first order kinetics and was triggered by drug diffusion and erosion of microspheres. From the above release results, it was observed that the formulation has the potential to sustain the drug release for more than 8 hours. Thus this Gastro retentive Sustained release drug delivery system is very helpful in increasing the efficiency of the dose, safety of dose as well as the patient compliance.

\section{REFERENCES}

1. Chiman LB, Richa S, Hemraj, Avneet G. Stomach Specific Mucoadhesive Microspheres as Controlled Drug Delivery System-A Review. Int. J. of Pharm. Pharm. Sci 2013; 5(2): 21-26.

2. Garg A, Upadhyay P. Mucoadhesive Microspheres: A Short Review. Asian J Pharm and Clinical Res 2012; 5 Suppl 3: 24-27.

3. Deshmukh T, Deshmukh V, Jadhav P, Kasat K, Patil R. Formulation and Evaluation of Mucoadhesive Microspheres of Ziprasidone Hydrochloride for Oral Controlled Release. Current Pharma Research 2012; 2(2): 497-502.

4. Kaurav H, Hari Kumar SL, Kaur A. Mucoadhesive Microspheres as carriers in Drug Delivery: a Review. Int. J. Drug Dvlpt and Res 2012; $4(2)$.

5. S Kataria, A Middha, P Sandhu, A Bilandi and B Kapoor. Microsphere: A Review. Int J Res Pharm Chem 2011; 1(4): 1185-1198.

6. Mathiowitz E, Chickering DE. Definitions, mechanisms and theories of Bioadhesion, in: Mathiowitz E, Chickering DE, Lehr, CM (Eds.), Bio adhesive Drug Delivery Systems: Fundamentals, Novel Approaches and Development, Marcel Decker, New York; 1999. p. 1-10, 541-562.

7. Khandai Madhusmruti, Chakraborty Santanu, Pathak Anirban, Ghosh Ashok Kumar. Algino Losartan Mucoadhesive Microspheres: An Unique Device for Prolonged Drug Delivery. Int. J. Pharm. Sci. Rev. Res 2013; 18(2): 50-57.

8. Das MK, Senapati SC. Evaluation of Furosemide Loaded Alginate Microspheres Prepared By Ionotropic External Gelation Technique. Acta Poloniae Pharmaceutica N Drug Research 2007; 64(3): 253-262.

9. B Brahmaiah, Desu Prasanna Kumar, Nama Sreekanth, Sd Khalilullah, $\mathrm{S}$ Satish Babu. Formulation and evaluation of extended release mucoadhesive microspheres of simvastatin. Int J Pharm Biomed Res 2013; 4(1): 57-64.

10. GV Radhe et al. Formulation and evaluation of mucoadhesive microspheres of nifedipine. J. Pharm. scientific innovation 2012; 1(5): $39-43$.

11. Deshmukh T, Deshmukh V, Jadhav P, Kasat K, Patil R. Formulation and Evaluation of Mucoadhesive Microspheres of Ziprasidone Hydrochloride for Oral Controlled Release. Current Pharma Research 2012; 2(2): 497-502.

12. Muzaffar F, N Murthy Venkatesh, Paul P, Semwal Ravindra, Pandey Shivanand. Formulation and Evaluation of Mucoadhesive Microspheres of Amoxicillin Trihydrate by using Eudragit RS 100. Int. J. Chem Tech Res 2010; 2(1): 466-470.

13. Yadav A, Jain Dinesh Kumar. Formulation and evaluation of mucoadhesive microspheres of propranolol hydrochloride for sustained drug delivery. Asian J. Pharm. Medical Sci 2011; 1(1): 1-8.

14. Shah R, Patel A, Jadhav A. Development and Evaluation of Mucoadhesive Algino HPMC Micro-particulate system of Aceclofenac 
for oral sustained drug delivery. Indian J. Pharma. Edu. Res 2012; 46(2): $120-128$.

15. Keyur SP, Mandev BP, Ankit AA, Pranit BP, Kinjal BR. Formulation and Evaluation of Nicorandil Microspheres. Int J Pharm Pharm Sci 2013; 5(2): 593-597.
Cite this article as:

Prabhudesai Gandha P., Gude Rajashree. Fabrication and characterization of gastroretentive mucoadhesive micro-particulate system of Pioglitazone hydrochloride for sustained delivery. Int. Res. J. Pharm. 2013; 4(11):57-63 http://dx.doi.org/10.7897/2230-8407.041114

Source of support: Nil, Conflict of interest: None Declared 